\title{
IMPACT OF REAL PROPERTY MARKET ON CHANGES OF CADASTRAL VALUE AND FORMATION OF SAMARA REGIONAL BUDGET
}

\author{
Gabibulla Khasaev ${ }^{1,}$ Dr.Sc., professor; Alexandr Vlasov ${ }^{2}$, Cand.Sc., professor; \\ Dariya Vasilieva $^{3,}$ Cand.Sc., docent; Valentin Lobanov ${ }^{4}$ and Velta Parsova ${ }^{4}$ Dr.oec., professor \\ 1,2,35amara State University of Economics, Russia, ${ }^{4}$ Samara Territorial appraisal Agency, Russia, \\ ${ }^{5}$ Latvia University of Life Sciences and Technologies
}

\begin{abstract}
In the Russian Federation, since 2014 the rules for calculating property taxes have been changed. The tax on real property increased several times as its value began to be formed from the cadastral value. The article examines the issues of changing the cadastral value of real property objects (land parcels and buildings) in the Samara region as a result of their disputing. The disputing of the cadastral value from which the tax payments are calculated is conducted in a specially created Dispute Commissions or by a court decision. The revision of the cadastral value is carried out on the basis of its market value on the date on which its cadastral value is established. In the Samara region currently the results of the cadastral valuation carried out in 20112013 are approved and used for taxation purposes. Analysis of the performed cadastral valuation work of this period showed that it was performed in low quality and the results of established cadastral value do not correspond to the indicators of market value at the date of the assessment. Excess of cadastral value over the market value is the basis for making decision on reducing the cadastral value of the real property. In this way, amount of taxes to be paid to the regional budget by taxpayers, mainly large industrial enterprises located on the territory of the Samara region, is reduced. As a result, the regional budget does not receive part of the planned revenue.
\end{abstract}

Key words: cadastral value, land stock, leasehold payment, market value, regional budget. JEL code: H30; K34

\section{Introduction}

The payment for land use in Russia is introduced since 1992, after adoption of the Law "On payment for land". This law provided for the following types of payments - land tax and leasehold payment (Law of the Russian Federation ..., 2000). Land tax plays an important role in the tax system, because it is one of the main sources of the formation of the financial base of local governments, and therefore it has significant impact on the socio-economic development of regions (Varlamov A., 2011; Varlamov A., 2014). Land tax, despite a relatively low share in total revenue, relates to local taxes (The Tax Code ..., 2000). The importance of updating of cadastral information for the collection of land payments is shown in publications by different authors (Baumane $\mathrm{V}$., 2016; Varlamov A., 2014; Galchenko S., 2003; Vlasov A., 2013; Koryagina N., 2008; Konstantinova E., 2015; Molzhitova D., 2013; Parsova V., Cahrausa I., 2015; Pomelov A., 2013).

The dynamics of the growth of land payments in the Samara region were analysed in our previous publications (Khasayev, G., 2016; Khasayev, G., 2017). The aim of this article is to analyse the impact of real property market value on formation of cadastral value and, in general, on collection of tax payments and formation of a regional budget.

The Samara region is located in the southeast of European Russia in the middle flow of the Volga. It covers an area of 53.6 thousand $\mathrm{km}^{2}(0.31 \%$ of the territory of Russia). The Samara region consists of 10 urban districts and 27 municipal districts. On 01.01.2016, the structure of the land stock has the following breakdown: agricultural land - $76 \%$, forest land - $10 \%$, urban land $7 \%$, industrial, transport and other special purpose land - $1 \%$, land of specially protected areas $3 \%$, land under water $-3 \%$. According to the status of ownership, the state and municipal property, including undistributed state ownership in land, occupies 2492 thousand hectares. The total ownership of citizens consists of 1933 thousand hectares (Report on the state ..., 2016). 


\section{Research results and discussion}

In 2014, the Russian Federation adopted amendments to the Tax Code of the Russian Federation, which changed the rules for calculating property taxes. Land parcels, buildings and structures were defined as real property objects, as well as residential and non-residential premises and objects of unfinished construction. Until 2015, the tax on property of physical persons in accordance with the Law "On Real Property Taxes" was calculated on the basis of data on the inventory value of buildings and structures. The normative price was established to the land, but land parcels were not taxed. Later in the regions of the Russian Federation, there were accepted laws on the transition to cadastral value as basis for calculation of real property tax. So, Samara region in 2015 started calculation of the real property tax for physical persons based on the cadastral value of real property objects - land parcels and buildings and structures. At the same time, taxation of real properties on the basis of cadastral value has been introduced gradually, taking into consideration an accumulation of the data in cadastre database. In the Russian Federation, each region by itself determined the list of taxpayers who will be affected by the new taxation order. Annually, the authorized body of executive authority of the Samara region compiles a list of real property objects, which will be taxed according to cadastral value. During last three years, there was a quantitative growth (13 times) of real properties, included in the list, which was aimed to increase the revenue part of consolidated budget of the Samara region.

After changing the system of calculation of real property tax of its cadastral value, the tax increased several times, despite a gradual increase in tax rates: in $2016-0.9 \%$, in $2017-1.2 \%$, in $2018-1.5 \%$, in $2019-1.8 \%$, in 2020 and in subsequent years $-2.0 \%$. The question of the correctness of determining the cadastral value of land and buildings used for taxation purposes is becoming topical.

Cadastral valuation of urban land is a combination of administrative and technical measures to establish the cadastral value of land parcels and buildings on territory of administrative unit within the boundaries of assessment zones. The valuation is carried out on the basis of:

- a comprehensive income;

- comparative and cost approach;

- information on transactions on real property market;

- level of leasehold payments;

- profitability of land use.

There are analysed leasehold-forming factors in the assessment process, including the quality and location of land parcels, improvements made in real property, level of social and engineering infrastructure of the territory etc. Peculiar parameters of land cadastral value obtained as a result of assessment are used to justify property tax rates, privatisation of the land, determination of leasehold payments, concluding inheritance contracts and gift agreements, mortgage operations, setting redemption prices in case of land expropriation, calculation of the starting price in the sale of land at auction etc.

The state cadastral valuation of the land is based on land classification according to the purpose and type of functional use, taking into account homogeneous by purpose the price zoning of the territory, type of functional use and land parcels with analogous cadastral value. The factors of existing buildings and land use, location of linear objects (streets, roads, rivers, waterways, 
overpasses, railways, etc.), as well as boundaries of cadastral areas or cadastral blocks are taken into account.

In accordance with the legislation of the Russian Federation, the cadastral value is the market value of real property objects established on a certain date on the basis of adopted techniques using technologies of mass-valuation. Cadastral value fairly objectively reflects the level of prices on the real property market, so the tax based on the market data is fair. According to the current legislation, the state cadastral valuation of land is carried out at least once every 5 years, on the territory of the Samara region it has been already conducted three times. The Figure 1 shows the change of peculiar parameters of land cadastral value on the example of one of the cadastral blocks of the Samara city (Fig. 1).

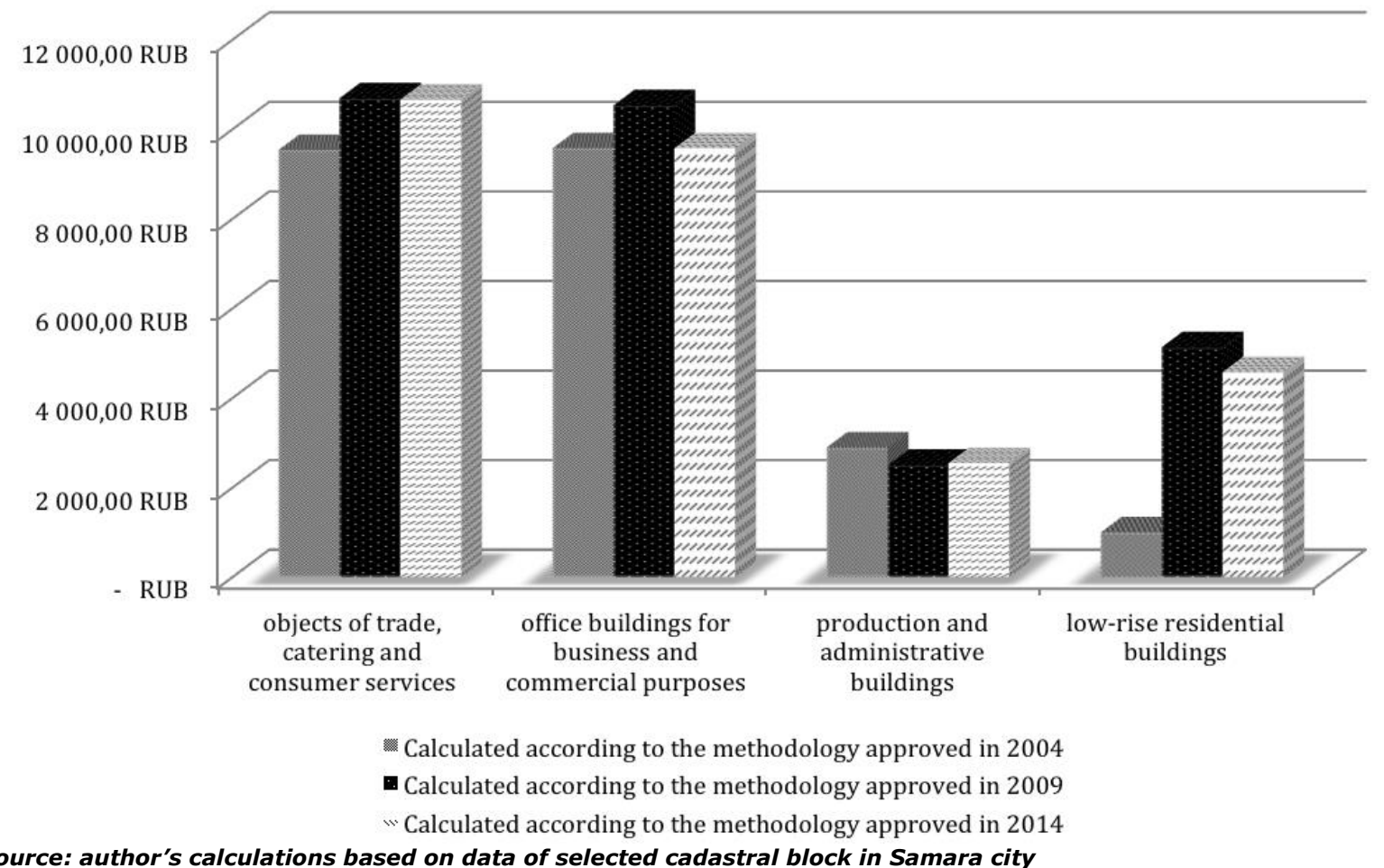

Fig. 1. Change of peculiar parameters of land cadastral value in (example of concrete cadastral block in Samara city, 2004 - 2014)

There are analysed changes of peculiar parameters of land cadastral value depending on the type of permitted use - land parcels intended for placement of:

- trade, catering and consumer services facilities;

- office buildings for business and commercial purposes;

- industrial and administrative buildings, industrial structures, communal services, material and technical, food supply, marketing and procurement

- low-rise housing, including individual housing development.

It should be noted, that peculiar parameter of land cadastral value for office buildings for business and commercial purposes is growing noticeably.

Peculiar parameters of land cadastral value in particular cadastral block are used as a base unit. In cadastral blocs, the base values coincide on the principle of similarity and are determined in accordance with methods taking into account all characteristics of the land. Fixation of the specific 
cadastral value index for area of the real property object allows calculating the cadastral value of the real property object.

The current cadastral value of land parcels and buildings was determined as a result of cadastral assessment carried out in 2011-2013. In urban area of Samara region, cadastral valuation of the buildings was carried out in 2011, but cadastral valuation of the land - in 2013. These results were included in the real property state cadastre. These data since 2014 are applied for taxation purposes according to the annually updated list of taxpayers. Non-listed owners still are taxed according to inventory value. The problems of incorrect cadastral valuation in period 2011-2013 are inherent to both land and buildings, and are discussed below.

At present, the problem of insufficient reliability to the results of current cadastral valuation is urgent. In spite of the fact that it was carried out according to the approved cadastral valuation methods, the reference material of analysis of transactions on real property market in calculations was used incorrectly. Not all the necessary factors were taken into account, for example, peculiarities of certain districts, which were located far from the city centre, were not considered. As a result, real properties located in some parts of the city, and used mainly as large industrial enterprises have been significantly overvalued.

According to the current legislation, updating of the cadastral value should be carried out no less than once in 5 years. In 2016, updating was done but its results were not approved and cannot be used for taxation purposes.

The authors have prepared a comparison between current cadastral values and market prices (Fig. 2).

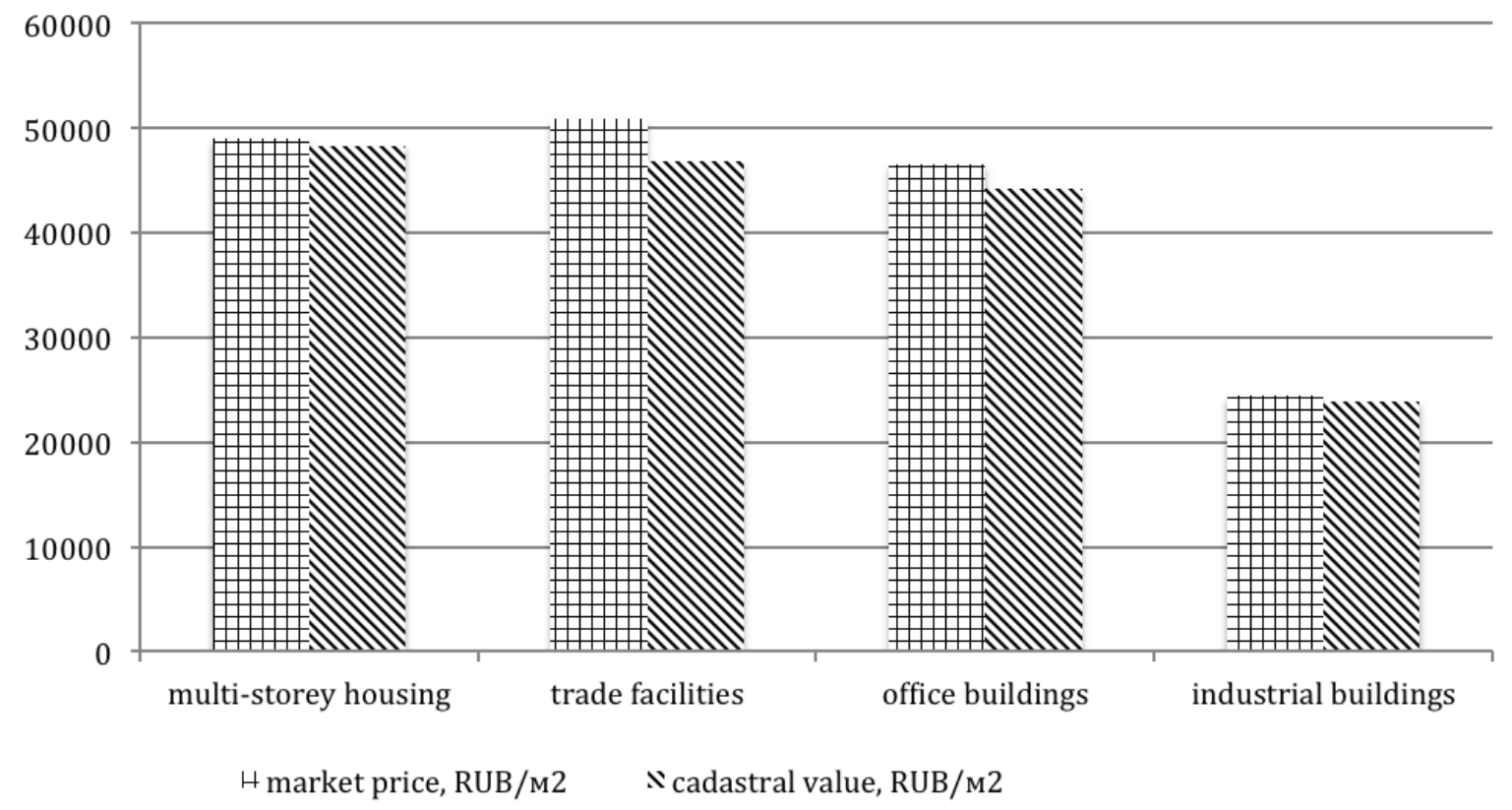

Source: author's calculations based on data of cadastral values and market prices

Fig. 2. Comparison of average cadastral values and market prices in Samara city (2016)

The figure shows that average value of peculiar parameters of cadastral value in Samara city is close to the average market value of objects for various purposes. However, in some cases, discrepancy can be more than five times. For example, a significant discrepancy is noted for the objects of trade and administrative and office facilities. 
Comparing the results of market and cadastral values of office and trade facilities, it is evident that in the central urban area the difference between mass-appraisal data is insignificant. However, if we consider similar objects that are located on the urban outskirts, there cadastral value is about 4-5 times higher than market value (Fig. 3).

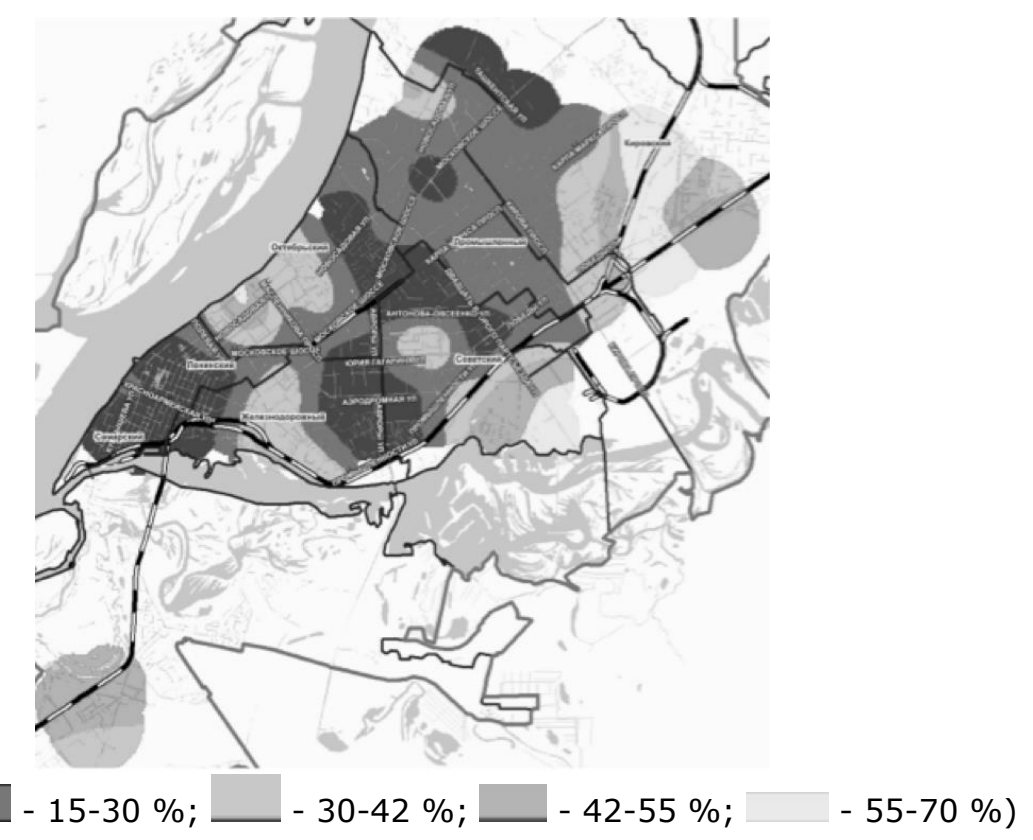

Source: author's calculations based on data of cadastral values and market prices

Fig. 3. The difference between the market and cadastral value of the trade facilities, \%

However, along with overvalued objects, there are objects that have been undervalued.

The reasons for changing the cadastral or market value can be related to the insufficient consideration of factors related to the location of a particular real property (Fig. 4).

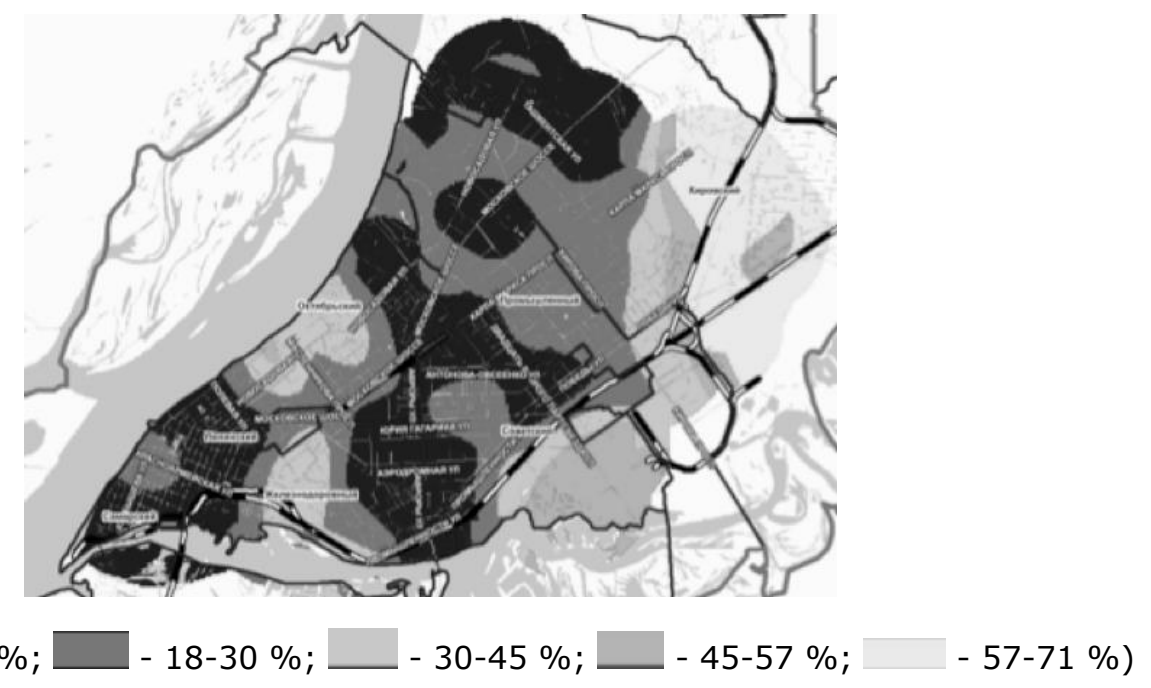

Source: author's calculations based on data of cadastral values and market prices

Fig. 4. The difference between the market and cadastral value of the administrative and office facilities, \%

The figures show that the areas located far from city business centre were significantly overvalued.

Excessive dissatisfaction for massive part of taxpayers is caused by low quality of cadastral assessments conducted in the region, which is the reason for appeals in commissions and courts. 
According to the results of 2014-2016, up to $9 \%$ of all appeals in the Russian Federation relates to the Samara region, which confirms the disproportionate, non-market based taxation. The basis for appeals and revising the cadastral value is its market value on the date, at which cadastral value was established. As evidence of it serves materials from market value databases.

As a rule, Commission reduced the cadastral value of land owned by the largest taxpayers industrial enterprises located in the majority of urban districts of the Samara region. Because of appeals, the cumulative value of the cadastral value in Samara region decreased by 129595644 thousand roubles, including cadastral value of the land by 121452890 thousand roubles (about $94 \%$ ) and buildings by 8142754 thousand roubles (about $6 \%$ ).

As a result, revenues to budgets of municipalities decreased. In general, for Samara region volume of outstanding tax payments due to the revision of the cadastral value in 2014-2016 is shown in the table (Table 1 ). Outstanding incomes in the local municipality budgets are formed from income of land tax, which was calculated at the tax rate of $1.5 \%$, and of tax payments for buildings, owned by physical persons, which was calculated at the current tax rate of $0.1 \%$.

\section{Amount of outstanding incomes in the budget of the Samara region} in 2014-2016

\begin{tabular}{|l|l|c|c|c|c|}
\hline No & \multicolumn{1}{|c|}{ The revision of the cadastral value } & $\mathbf{2 0 1 4}$ & $\mathbf{2 0 1 5}$ & $\mathbf{2 0 1 6}$ & $\begin{array}{c}\text { In total } \\
\mathbf{2 0 1 4}-\mathbf{2 0 1 6}\end{array}$ \\
\hline $\mathbf{1 .}$ & $\begin{array}{l}\text { Reduction of cadastral value of the land, } \\
\text { RUB }\end{array}$ & 51221664 & 35140415 & 35090811 & $\mathbf{1 2 1} \mathbf{4 5 2} \mathbf{8 9 0}$ \\
\hline $\mathbf{2 .}$ & $\begin{array}{l}\text { Outstanding income from land tax, } \\
\text { calculated at a rate of } 1.5 \%, \text { RUB }\end{array}$ & 768325 & 527107 & 526362 & $\mathbf{1 8 2 1} \mathbf{7 9 4}$ \\
\hline $\mathbf{3 .}$ & $\begin{array}{l}\text { Decrease of cadastral value due to } \\
\text { applications of owners - physical } \\
\text { persons, RUB }\end{array}$ & 42930 & 215228 & 967552 & $\mathbf{1 2 2 5} \mathbf{7 1 0}$ \\
\hline $\mathbf{4 .}$ & $\begin{array}{l}\text { Outstanding income from physical } \\
\text { persons land tax, calculated at a rate of } \\
\text { 0.1\%, RUB }\end{array}$ & 0 & 215 & 967 & $\mathbf{1 ~ 1 8 2}$ \\
\hline & $\begin{array}{l}\text { Outstanding income in municipality } \\
\text { budgets in total }\end{array}$ & 768325 & 527322 & 527329 & $\mathbf{1 8 2 2} \mathbf{9 7 6}$ \\
\hline
\end{tabular}

Source: author's calculations based on reports of the Accounts Chamber of the Samara Region

The total amount of outstanding revenues (real property tax) in the consolidated budget of Samara region due to revised cadastral value by Commissions and in the legal procedure during the period under study makes 1822976 thousand roubles, including land tax 1821794 thousand roubles (99\%).

\section{Conclusions, proposals, recommendations}

1) The impact of real property market to the cadastral value is an important factor, underestimation of which leads to serious consequences.

2) Reducing the cadastral value of land and buildings reduces revenues in the municipal budgets through real property tax, which is calculated on the basis of cadastral value.

3) The reason for reduced revenues is an imperfection of the mechanism for formation and actualization of information about real property for taxation purposes, lack of responsibility carrying out of cadastral valuation, as well as procedures of quality control. 


\section{Bibliography}

1. Baumane, V. (2016). Analysis of Impact of Land Quality Assessment in Regions of Latvia for Agriculture Land Value. Proceedings of scientific methodical conference "Baltic Surveying'16" pp. 14-20.

2. Galchenko, S.A. (2003). The Effectiveness of the System of the State Land Cadastre of Different Administrative-territorial Levels. M.: MGIU. 158 p.

3. Khasaev, G.R., Vlasov, A.G., Vasilieva, D.I., Chepurin, E.M., Lobanov, V.P. , Volodina, T.V. (2016). Cadastral Valuation of Real Estate in the Socio-economic Development of Region (on the example of Samara region). Land management, cadastre and monitoring of lands. Volume 3 (134). pp. 51-60.

4. Khasaev, G.R., Vlasov, A.G., Vasilieva, D.I. 2017. Modeling and Analysis of the Collection of Land Payments in the Municipal Areas, Depending on the Economic and Geographical Factors // Baltic surveying. International scientific journal. 2017. Volume 6, pp. 71-79.

5. Konstantinova, E.P. (2015) Improving the Efficiency of Land Administration in the Municipalities. Bulletin of Volga region Institute of management. Volume 1. pp. 17-22

6. Koryagina, H.B. (2008) The Evaluation of the Effectiveness of Land Administration in the Kuznetsk district of the Penza region. Science and technology of APC. Volume 11. pp. 11-12.

7. Law of the Russian Federation of 11.10.1991 № 1738-1 "On payment for land".

8. Molzhitova, D., Igembaeva, S., Gurklys, V. (2013) Problems and Basic Directions of Perfection of Management of Land Resources of the Republic of Kazakhstan. Proceedings of scientific methodical conference "Baltic Surveying'13". pp. 116-120.

9. Parsova, V., Cahrausa, I. (2015) Prevention of Land Degradation Processes. Baltic Surveying International Scientific Journal. Volume 3. pp. 73-78.

10. Pomelov, A. (2013) Mechanism of Regulation of Land Use in Belarus. Proceedings of scientific methodical conference "Baltic Surveying'13". pp. 126-134.

11. Report on the State and Use of Land in the Samara region in 2015. - 2016. Federal Service of State Registration, Cadastre and Cartography Department of the Federal Service for State Registration, Cadastre and Cartography of the Samara Region. - Samara.

12. The Tax Code of the Russian Federation (part two) of 05.08.2000 No. 117-FZ.

13. Varlamov, A.A. (2011) Organizational and Legal Mechanisms of Land Survey and Cadastral Ensure Agricultural Lands / Sc. red. Varlamov A.A. State University of land management. M., 2011. 208 p.

14. Varlamov, A.A. 2014. System of State and Municipal Management. M.: State University for Land Management. $452 \mathrm{p}$.

15. Vlasov, A.G., Voronin, V.V., Vasilieva, D.I. (2013) Legislative Framework of Land and Property Complex. Problems of Regional Ecology. Volume 4. pp. 117-121. 